\title{
Hemşirelerin Tabi Oldukları Mevzuat ve Hukuki Sorumlulukları Konusundaki Farkındalıkları
}

\author{
Awareness of Nursing Legislations and Legal Responsibilities among Nurses
}

Belkız Karabakır', Gürsel Çetin ${ }^{2}$

${ }^{I}$ Koç Üniversitesi Tıp Fakültesi Genel Cerrahi Anabilim Dall, İstanbul

${ }^{2}$ Ístanbul Üniversitesi Cerrahpaşa Tıp Fakültesi Adli Tıp Anabilim Dalı, İstanbul

\section{Özet}

Amaç: Hemşirelik uygulamalarında gerek mesleki gerek ise hukuki sorumluluk açısından bilgisizlikler, belirsizlikler olduğu öngörülmekte olup; çalışma ile hemşirelerin tabi oldukları mevzuat ve hukuki sorumluluklarına ilişkin bilgi ve farkındalık düzeylerinin belirlenmesi, mevcut bilgi eksikliğine dikkat çekerek hukuki sorunlar ile karşılaşmamaları için yapılması gereken çalışmalar ve alınması gereken önlemlerin ortaya konulması amaçlanmıştır.

Gereç ve Yöntem: Tanımlayıcı nitelikteki çalışmada; İstanbul Üniversitesi Cerrahpaşa Tıp Fakültesi Hastanesi'nde görev almakta olan hemşirelerden ( $\mathrm{n}=950$ ) ulaşılabilen ve çalışmayı kabul eden 606 tanesi ile çalışılmıştır. Veriler; yüz yüze yöntemiyle 25 sorudan oluşan bir anket formu kullanılarak toplanmış, SPSS 14 programı ile değerlendirilmiş ve mezuniyet durumu, şu an ve/ veya önceden çalışılan birim, mesleki deneyim ile konuya ilişkin eğitim almıș olup olmama gibi değișkenlere göre farklılıklar s1nanmıştır. Veriler arasındaki ilişkiler istatistiksel olarak Ki-kare testi ile araştırılmış; $\mathrm{p} \leq 0.05$ değerleri anlamlı kabul edilmiştir.

Bulgular: Hemşirelerin önemli bir bölümü tabi oldukları mevzuatı ve hukuki sorumluluklarını bilmemekte veya yanlış bilmektedir. Ayrıca, farklı birimlerdeki katılımcıların cevapları arasında anlamlı farkl1lık saptanmazken; eğitim düzeyi, mesleki deneyim, konuya ilişkin eğitim almış olup olmama durumları ile katılımcıların cevapları arasında istatistiksel olarak anlamlı bir ilişki saptanmıştır.

Sonuç: Bulgular; konuya yönelik hizmet içi eğitimlere ek olarak, kıdem farkı gözetmeksizin bu eğitimlerin periyodik olarak tekrarını gerekli kılmıştır.

Anahtar Kelimeler: Hemşire; Mevzuat; Hukuki sorumluluk; Farkındalık; Malpraktis.

\section{Giris}

Hemşirelik; birey, aile ve toplumun sağlığını ve esenliğini koruma, geliştirme ve hastalık durumunda iyileştirmeye yönelik çabaların tümünde yer almaktadır. Hemşire;

Sorumlu Yazar: Dr. Belkız Karabakır

Koç Üniversitesi Tıp Fakültesi

Genel Cerrahi Bölümü, İstanbul

E-mail: belkis.karabakir@hotmail.com

Geliş: 01.03.2016 Düzeltme: 17.05.2016 Kabul: 21.06.2016

\begin{abstract}
Objective: To avoid legislative complications in nursing, it is important for the nurses to know their professional and legal responsibilities. Therefore, we aimed to investigate the awareness and cognizance of nurses toward these issues in order to determine the subjects that are not well-known and to propose actions to mediate this problem.
\end{abstract}

Materials and Methods: The descriptive research was conducted at the Istanbul University, Hospital of the Cerrahpasa Medical Faculty; from the approached 950 nurses a total of 606 participated in this study. The data was collected using a 25 -item questionnaire using the face-to-face method. The data obtained was statistically analyzed using SPSS 14 with respect to: education, the current and/or previous work unit, proficiency and previous educational training regarding these issues. The statistical connection amongst data was determined using the chi-square test and values of $\mathrm{p} \leq 0.05$ were considered significant.

Results: A significant proportion of the nurses are not aware of their legal and professional responsibilities or are misinformed. We found no connection between the level of knowledge and their unit of employment but found a significant correlation with their level of education, professional experience, history of specific education for nursing responsibilities and legislation.

Conclusion: In conclusion it is suggested that additional training on these issues should be carried out periodically for all nurses independent of hierarchy.

Keywords: Nurse; Legislation; Legal responsibility; Awareness; Malpractice.

sağlık bakımını bağımsız, yarı bağımlı ve bağımlı rollerle sunar. Hemşireler, Hemşirelik Kanunu başta olmak üzere ilgili yasa ve yönetmeliklere uygun şekilde hemşirelik işlevlerini yerine getirirler. Yasaların yanı sıra etik ilkelerin hemşirelere yüklediği sorumluluklar, bireyin güvenliğini ve yararını sağlamayı ve zarar görmesini engelleyen bazı önlemlerin alınmasını gerektirir $(1,2)$.

$\mathrm{Bu}$ nedenle hemşirelerin meslekleri ile ilgili yasa, tüzük ve yönetmelikleri değerlendirerek; haklarının, 
yetkilerinin ve sorumluluklarının neler olduğunu ve bunların nasıl korunup kullanılacağını bilmeleri meslek hukuku açısından birçok sorunun üstesinden gelmelerine yardımcı olacaktır. Yasaları bilmeden yapılan bazı girişimler, hemşireyi yasalar önünde suçlu duruma düşürebilir (3).

Sağlık çalışanlarının büyük çoğunluğu kendileri ile ilgili yasa, tüzük ve yönetmelikleri bilmemektedir (4). 5237 sayılı Türk Ceza Kanunu (TCK)'nun 4. maddesinde "Ceza kanunlarını bilmemek mazeret sayılmaz" ifadesi yer almaktadır (5). Dolayısıyla hemşireler, mesleklerinin gerektirdiği yetki ve sorumlulukları düzenleyen yasal düzenlemeleri bilmek ve uygulamalarını bu çerçevede yürütmek durumundadır.

Ayrıca hemşirelerin uygulamada çok çeşitli görevleri olmasına rağmen yasalarda çok azı belirtilmektedir. Bunun önemli nedenlerinden biri de sağllk hukukunda gözden kaçırılmaması gereken bazı eksiklikleridir. Ayrıca ülkemizde hemşirelik hizmetlerinin çağdaş görünümü için bir örgütlenme yapısı bulunmamaktadır. Değişik düzeylerde eğitim alarak gelen hemşirelerin aynı unvan ile istihdam edilmeleri, uygulamada görev tanımlarının net olmaması veya diğer sağlık personeliyle görev çatışmalarına neden olabilen mevzuatların varlığı sorunlara yol açabilmektedir (6).

Netice itibariyle, hemşirelik uygulamalarında gerek mesleki gerek ise hukuki sorumluluk açısından bilgisizlikler, belirsizlikler olduğu öngörülmekte olup; çalışma ile hemşirelerin tabi oldukları mevzuat ve hukuki sorumluluklarına ilişkin bilgi ve farkındalık düzeylerinin belirlenmesi, mevcut bilgi eksikliğine dikkat çekerek hukuki sorunlar ile karşı karşıya kalmamaları için yapılması gereken çalışmalar ve alınması gereken önlemlerin ortaya konulması amaçlanmıştır.

\section{Gereç ve Yöntem}

Çalışma öncesi İstanbul Üniversitesi Cerrahpaşa Tıp Fakültesi Dekanlığı'ndan gerekli izin alınmış olup, OcakMart 2010 tarihleri arasında Cerrahpaşa Tip Fakültesi Hastanesi'nde görev almakta olan hemşirelerden ulaşılabilen ve çalışmayı kabul eden 606 hemşire ile çalışılmıştır. Veriler, yüz yüze yöntemiyle araştırmacı tarafından oluşturulmuş bir anket formu kullanılarak toplanmıștır. Sorulara verilen yanıtlar SPSS 14 programı kullanılarak değerlendirilmiş ve mezuniyet durumu, şu an ve/veya önceden çalışllan birim, mesleki tecrübe süresi ile tabi olunan mevzuata veya hukuki sorumluluklara ilişkin eğitim almış olup olmama gibi değişkenlere göre farklılıklar sınanmıştır. Veriler arasındaki ilişkiler istatistiksel olarak, $\mathrm{Ki}$-kare testi ile araştırılmış olup; $\mathrm{p} \leq 0.05$ değerleri anlamlı kabul edilmiştir.

\section{Bulgular}

Katılımcıların en küçügü̈ 19, en büyüğü 61 yaşındadır. Yaş ortalaması 30'dur. \%95,4'ü $(n=578)$ kadındır. \%58,3'ü $(n=353)$ lisans, \%26,9'u ( $\mathrm{n}=163)$ ön lisans, $\% 7,8$ 'i (n=47) yüksek lisans/doktora, \%7,1'i $(n=43)$ lise mezunudur. \%39,8'i $(\mathrm{n}=241)$ cerrahi, \%32,7'si $(\mathrm{n}=198)$ dahili, \%27,6's1 ( $\mathrm{n}=167)$ hem cerrahi hem dahili tı bilimlerde görev almakta ve/veya almıştır. \%66,3'ü (n=402) 0-10 y1l, \%18,2'si ( $n=110)$ 11-20 yıl, \%15,5'i (n=94) 20 y1lı aşkın süredir hemşirelik mesleğini icra etmektedir. \%55,6's1 (n=337) tabi oldukları mevzuat veya hukuki sorumluluklarına ilişkin herhangi bir eğitim almadığını, $\% 44,4$ 'ü (n=269) konuyla ilgili eğitim aldığını belirtmiştir.

"TCK'da mesleki sorumluluk açısından hekimler için ayrı, hemşireler için ayrı maddeler vardır” şeklindeki 8. soruya katılımcıların $\% 55$ 'i $(n=330)$ doğru, \%37'si ( $\mathrm{n}=224)$ bilmiyorum biçiminde cevap vermiştir. $\mathrm{Bu}$ sorunun doğru cevabı "Yanlış" olup buna göre; katılımcıların \%8'i soruyu doğru olarak yanıtlayabilmiştir (Grafik 1). Farklı mezuniyet seviyesindeki katılımcıların cevapları arasında anlamlı farklılık saptanmıştır. Ön lisans mezunlarının "Bilmiyorum" cevabını verme oranı anlamlı derecede yüksek bulunmuştur. Bu grupta cevap verenlerin yanılma oranları ise anlamlı derecede düşüktür $(p=0.000)$. Eğitim almış olan katılımcılar ile eğitim almamış olanların cevapları arasında anlamlı farklılık saptanmıştır. Eğitim alanların "Bilmiyorum" cevabını verme oranı anlamlı derecede düşüktür ve "Yanlış" cevabını işaretleyen bireylerin dörtte üçü bu gruptadır $(\mathrm{p}=0.000)$. Farklı birimlerdeki katılımcıların cevapları arasında anlamlı farklılık saptanmıştır. Dahili tıp bilimlerinde çalışan hemşirelerde yanılma oranı diğer gruplara göre daha düşüktür ( $\mathrm{p}=0.001$ ). Farklı mesleki tecrübe süresine sahip katılımcıların cevapları arasında anlamlı farklılık saptanmıştır. 0-10 y1l tecrübeye sahip hemşirelerin soruya "Bilmiyorum" yanıtını verme oranları düşük, yanılma oranlar1 yüksek bulunmuştur $(\mathrm{p}=0.000)$.

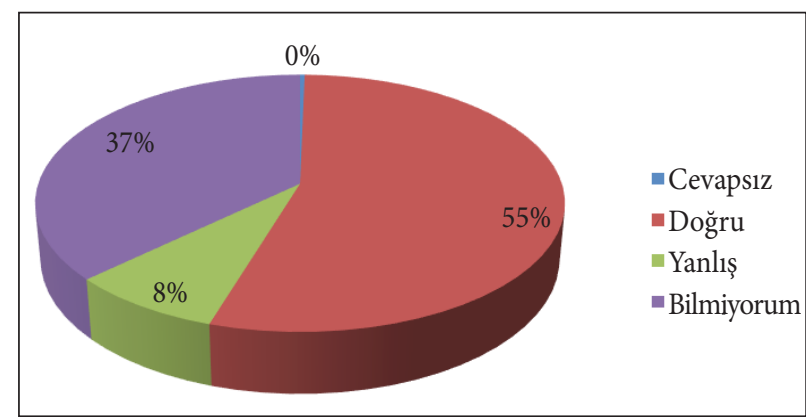

Grafik 1. "TCK' da mesleki sorumluluk açısından hekimler için ayrı, hemşireler için ayrı maddeler vardır" şeklindeki soruya verilen cevaplar. 
"Hemşireler, hatalı uygulamalarının olduğu iddiası ile haklarında açılan tazminat davalarında çarptırıldıkları tazminatı ödemekle yükümlü olmayıp, tazminat hastane yönetimi tarafından ödenir" şeklindeki 9. soruya katılımciların $\% 49,5$ ' $(n=300)$ bilmiyorum, $\% 39,4$ 'ü $(\mathrm{n}=239)$ yanlış, \%10,6'sı ( $\mathrm{n}=64)$ doğru biçiminde cevap verirken $\% 0,5^{\prime} \mathrm{i}(\mathrm{n}=3)$ de soruyu cevapsiz b1rakmıştır. Bu sorunun doğru cevabı "Yanlış" olup buna göre; katılımcıların \%39,4'ü soruyu doğru olarak yanıtlayabilmiştir. Farklı mezuniyet seviyesindeki katılımcıların cevapları arasında anlamlı farklılık saptanmıştır. "Bilmiyorum" cevabını verme oranı ön lisans mezunlarında yüksek, yüksek lisans/doktora mezunlarında düşükken, yüksek lisans/doktora mezunlarının istenen yanıtı bulma oranları yüksektir $(\mathrm{p}=0.000)$. Eğitim almış olan katılımc1lar ile eğitim almamış olanların cevapları arasında anlam1 farklılık saptanmıştır. Eğitim alanların "Bilmiyorum" cevabını verme oranı düşük, istenen yanıtı bulma oranı yüksektir ( $\mathrm{p}=0.000)$. Farklı birimlerde çalışan katılımc1ların cevapları arasında anlamlı farklılık saptanmamıştır $(p=0.484)$. Farklı mesleki tecrübe süresine sahip katılımc1ların cevapları arasında anlamlı farklılık saptanmıştır. 11 y1l ve üzeri tecrübeye sahip hemşirelerin "Bilmiyorum" cevabını verme oranları yüksektir, istenen cevabı bulma oranları ise düşüktür ( $\mathrm{p}=0.000)$ (Tablo 1).

Tablo 1. Mesleki sürelerine göre "Hemşireler, hatalı uygulamalarının olduğu iddiası ile haklarında açılan tazminat davalarında çarptırıldıkları tazminatı ödemekle yükümlü olmayıp, tazminat hastane yönetimi tarafindan ödenir" şeklindeki soruya verilen cevaplar.

\begin{tabular}{|l|l|l|l|}
\hline Mesleki süre & $\mathrm{n}(\%)$ & $\mathrm{n}(\%)$ & $\mathrm{n}(\%)$ \\
\hline & Doğru & Yanlış & Bilmiyorum \\
\hline $0-10$ yıl & $45(11,3)$ & $181(45,3)$ & $174(43,5)$ \\
\hline $11-20$ yıl & $8(7,3)$ & $34(31,2)$ & $67(61,5)$ \\
\hline 20 yıl üstü & $11(11,7)$ & $24(25,5)$ & $59(62,8)$ \\
\hline Toplam & $64(10,6)$ & $239(39,6)$ & $300(49,8)$ \\
\hline
\end{tabular}

"Mevzuatta hekim istemlerinin yazılı olması gerektiğine dair bir madde mevcut değildir" şeklindeki 10. soruya katılımcıların \%47,7'si $(\mathrm{n}=289)$ yanlış, \%40,3’ü (n=244) bilmiyorum, \%10,7'si (n=65) doğru biçiminde yanıt verirken $\% 1,3$ 'ü $(n=8)$ de soruyu yanıtsız bırakmıştır. Bu sorunun doğru cevabı "Yanlış" olup buna göre; katılımcıların \%47,7'si soruyu doğru olarak yanıtlayabilmiştir. Farklı mezuniyet seviyesindeki katılımcıların cevapları arasında anlamlı farklılık saptanmıştır. "Bil- miyorum" cevabını verme oranı ön lisans mezunlarında yüksek, yüksek lisans/doktora mezunlarında düşükken, yüksek lisans/doktora mezunlarının istenen yanıtı bulma oranları yüksektir ( $\mathrm{p}=0.000$ ). Eğitim almış olan katılımcılar ile eğitim almamış olanların cevapları arasında anlamlı farklılık saptanmıştır. Eğitim alanların "Bilmiyorum" cevabını verme oranları düşük, istenen yanıtı bulma oranları yüksektir $(p=0.000)$. Farklı birimlerde çalışan katılımcıların cevapları arasında anlamlı farklılık saptanmamıştır ( $\mathrm{p}=0.146)$. Farklı mesleki tecrübe süresine sahip katılımcıların cevapları arasında anlamlı farklılık saptanmamıştır $(\mathrm{p}=0.052)$.

"Hemşirenin, hastanın zarar görmesine yol açan kusurlu davranışı deneyimsizliğinden kaynaklanıyorsa, hukuksal sorumluluğu ortadan kalkar" şeklindeki 11. soruya katılımcıların $\% 67,3$ 'ü $(n=408)$ yanlış, \%28,7'si (n=174) bilmiyorum, \%4'ü ( $n=24)$ ise doğru biçiminde yanıt vermiştir. Bu sorunun doğru cevabı "Yanlış” olup buna göre; katılımcıların \%67,3'ü soruyu doğru olarak yanıtlayabilmiştir. Farklı mezuniyet seviyesindeki katılımcıların cevapları arasında anlamlı farklılık saptanmıştır. "Bilmiyorum" cevabını verme oranı ön lisans mezunlarında yüksek, yüksek lisans/doktora mezunlarında düşükken, yüksek lisans/doktora mezunlarının istenen yanıtı bulma oranları yüksektir ( $\mathrm{p}=0.022)$. Eğitim almış olan katılımcılar ile eğitim almamış olanların cevapları arasında anlamlı farklılık saptanmıştır. Eğitim alanların "Bilmiyorum" cevabını verme oranı düşük, istenen yanıtı bulma oranı yüksektir $(\mathrm{p}=0.001)$. Farklı birimlerde çalışan katılımcıların cevapları arasında anlamlı farklılık saptanmamıştır ( $\mathrm{p}=0.195)$. Farklı mesleki tecrübe süresine sahip katılımcıların cevapları arasında anlamlı farkl1lık saptanmıştır. 11 yıl ve üzeri tecrübeye sahip olanların "Bilmiyorum" cevabını verme oranları daha yüksektir $(\mathrm{p}=0.011)$.

"Hemşire, tedaviye bağlı olarak gelişen komplikasyonlardan sorumludur" şeklindeki 12. soruya katılımc1ların \%46,4'ü (n=281) doğru, \%32,5'i (n=197) yanlış, $\% 20,3$ 'ü $(n=123)$ bilmiyorum biçiminde cevap verirken $\% 0,8$ 'i $(n=5)$ ise soruyu yanıtsız bırakmıştır. Bu sorunun doğru cevabı "Yanlı̧̧" olup buna göre; katılımcıların \%32,5'i soruyu doğru olarak yanıtlayabilmiştir. Farklı mezuniyet seviyesindeki katılımcıların cevapları arasında anlamlı farklılık saptanmıştır. Ön lisans mezunlarının "Bilmiyorum" cevabını verme oranı anlamlı derecede yüksek bulunmuştur. Bu grupta cevap verenlerin yanılma oranları ise anlamlı derecede düşüktür $(p=0.027)$. Eğitim almış olan katılımcılar ile eğitim almamış olanların cevapları arasında anlamlı farklılık saptanmıştır. Eğitim alanların "Bilmiyorum" cevabını işaretleme oranı düşüktür ancak soruya verdikleri cevaplarda yanılma oranları 
yüksektir $(\mathrm{p}=0.000)$ (Tablo 2). Farklı birimlerde çalışan katılımcıların cevapları arasında anlamlı farklılık saptanmamıştır ( $\mathrm{p}=0.877)$. Farklı mesleki tecrübe süresine sahip katılımcıların cevapları arasında anlamlı farklılık saptanmıştır. 11 yıl ve üzeri tecrübeye sahip olanların "Bilmiyorum" cevabını verme oranları yüksek, soruya "Doğru" yanıtını vererek yanılma oranları düşüktür $(\mathrm{p}=0.002)$.

Tablo 2. Eğitim durumuna göre katılımcıların

"Hemşire, tedaviye bağlı olarak gelişen

komplikasyonlardan sorumludur" şeklindeki soruya verilen cevaplar.

\begin{tabular}{|l|l|l|l|}
\hline \multirow{2}{*}{ Ĕgitim durumu } & $\mathrm{n}(\%)$ & $\mathrm{n}(\%)$ & $\mathrm{n}(\%)$ \\
\cline { 2 - 4 } & Doğru & Yanlış & Bilmiyorum \\
\hline $\begin{array}{l}\text { Eğitim almış } \\
\text { olanlar }\end{array}$ & $150(56)$ & $83(31)$ & $35(13,1)$ \\
\hline $\begin{array}{l}\text { Eğitim almamış } \\
\text { olanlar }\end{array}$ & $131(39,3)$ & $\begin{array}{l}114 \\
(34,2)\end{array}$ & $88(26,4)$ \\
\hline Toplam & $281(46,8)$ & $\begin{array}{l}197 \\
(32,8)\end{array}$ & $123(20,5)$ \\
\hline
\end{tabular}

"Hekim endikasyon koymuşsa hastanın onamı olmasa bile enjeksiyon yapılmasında herhangi bir sakınca yoktur" şeklindeki 13. soruya katılımcıların \%71,8'i (n=435) yanlış, \%16,3'ü (n=99) bilmiyorum, $\% 11,6$ 's1 ( $\mathrm{n}=70)$ doğru biçiminde yanıt verirken \%0,3'ü $(\mathrm{n}=2)$ ise soruyu yanıtsız bırakmıştır. Bu sorunun doğru cevabı "Yanlış" olup buna göre; katılımcıların \%71,8'i soruyu doğru olarak yanıtlayabilmiştir. Farklı mezuniyet seviyesindeki katılımcıların cevapları arasında anlamlı farklılık saptanmıştır. Yüksek lisans/doktora mezunlarının "Bilmiyorum" cevabını verme ve yanılma oranları anlamlı derecede düşüktür ( $\mathrm{p}=0.001)$. Eğitim almış olan katılımcılar ile eğitim almamış olanların cevapları arasında anlamlı farklılık saptanmıştır. Eğitim alanların "Bilmiyorum" cevabını verme oranı anlamlı derecede düşüktür $(\mathrm{p}=0.001)$. Farklı birimlerde çalışan katılımcıların cevapları arasında anlamlı farklılık saptanmamıştır $(\mathrm{p}=0.144)$. Farklı mesleki tecrübe süresine sahip katılımcıların cevapları arasında anlamlı farklılık saptanmıştır. 20 yıl ve üzeri tecrübeye sahip olanların "Bilmiyorum" cevabını verme ve yanılma oranları yüksektir $(\mathrm{p}=0.015)$.

"Aydınlatılmış onam, hemşireyi mesleki uygulama hatalarından doğan sorumluluğa karşı korur" şeklindeki 14. soruya katılımcıların \%61,2'si $(n=371)$ doğru, \%21,5'i (n=130) yanlış biçiminde yanıt vermiştir. $\mathrm{Bu}$ sorunun doğru cevabı "Yanlış" olup buna göre; kat1lımcıların \%21,5'i soruyu doğru olarak yanıtlayabilmiştir
(Grafik 2). Farklı mezuniyet seviyesindeki katılımcıların cevapları arasında anlamlı farklılık saptanmıştır. Ön lisans mezunlarında "Bilmiyorum" cevabını verme oranı yüksek, yanılma oranı düşüktür ( $\mathrm{p}=0.033)$. Eğitim almış olan katılımcılar ile eğitim almamış olanların cevapları arasında anlamlı farklılık saptanmıştır. Eğitim alanların "Bilmiyorum" cevabını verme oranı anlamlı derecede düşüktür $(\mathrm{p}=0.001)$. Farklı birimlerde çalışan katılımc1ların cevapları arasında anlamlı farklılık saptanmamıştır $(\mathrm{p}=0.494)$. Farklı mesleki tecrübe süresine sahip katılımcıların cevapları arasında anlamlı farklılık saptanmıştır. 10 yıl ve altı tecrübeye sahip olanların yanılma oranları yüksektir $(\mathrm{p}=0.003)$.

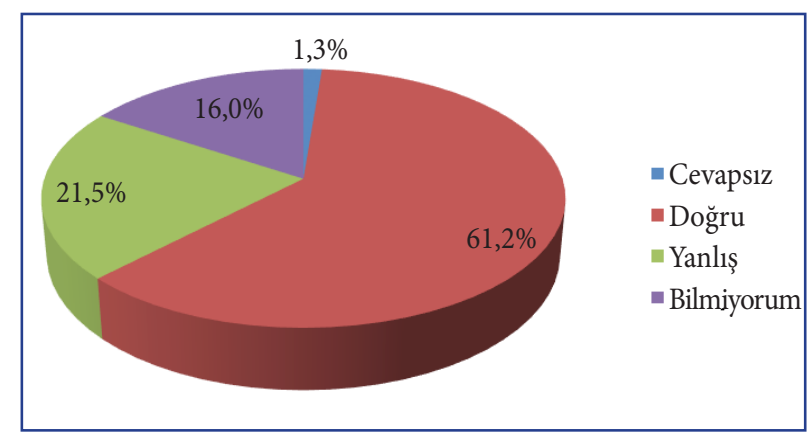

Grafik 2. "Aydınlatılmış onam, hemşireyi mesleki uygulama hatalarından doğan sorumluluğa karşs korur" şeklindeki soruya verilen cevaplar.

"Kayit tutma, hemşirenin sorumluluğunda olan bir şey değildir" şeklindeki 15. soruya katılımcıların $\% 88$ 'i ( $n=533$ ) yanlış, $\% 6,1$ 'i (n=37) bilmiyorum, $\% 5,3$ 'ü $(\mathrm{n}=32)$ doğru biçiminde yanıt verirken $\% 0,7$ 'si $(\mathrm{n}=4)$ ise soruyu yanıtsız bırakmıştır. Bu sorunun doğru cevabı "Yanlış" olup buna göre; katılımcıların \%88'i soruyu doğru olarak yanıtlayabilmiştir. Farklı mezuniyet seviyesindeki katılımcıların cevapları arasında anlamlı farklılık saptanmamıştır ( $p=0.201)$. Eğitim almış olan katılımcılar ile eğitim almamış olanların cevapları arasında anlamlı farklılık saptanmıştır. Eğitim alanların "Bilmiyorum" cevabını verme oranı düşüktür $(\mathrm{p}=0.002)$. Farklı birimlerde çalışan katılımcıların cevapları arasında anlamlı farklılık saptanmamıştır $(\mathrm{p}=0.104)$. Farklı mesleki tecrübe süresine sahip katılımcıların cevapları arasında anlamlı farkl1lık saptanmamıştır $(\mathrm{p}=0.321)$.

"Hemşirenin görevini yaptığı sırada bir suçun işlendiğine tanıklık etmesine rağmen bunu yetkili makamlara bildirmemesi suçtur" şeklindeki 16. soruya katılımciların \%78,7'si (n=477) doğru, \%14,7'si (n=89) bilmiyorum, \%5,4'ü $(\mathrm{n}=33)$ yanlış biçiminde cevap ve- 
rirken \%1,2'si ( $\mathrm{n}=7)$ ise soruyu yanıtsız bırakmıştır. $\mathrm{Bu}$ sorunun doğru cevab1 "Doğru" olup buna göre; katılımcıların \%78,7'si soruyu doğru olarak yanıtlayabilmiştir. Farklı mezuniyet seviyesindeki katılımcıların cevapları arasında anlamlı farklılık saptanmamıştır $(\mathrm{p}=0.328)$. Eğitim almış olan katılımcılar ile eğitim almamış olanların cevapları arasında anlamlı farklılık saptanmıştır. Eğitim alanlarda "Bilmiyorum" cevabını verme oranı anlamlı derecede düşüktür $(\mathrm{p}=0.000)$. Farklı birimlerde çalışan katılımcıların cevapları arasında anlamlı farklılık saptanmamıştır $(\mathrm{p}=0.798)$. Farklı mesleki tecrübe süresine sahip katılımcıların cevapları arasında anlamlı farklılık saptanmıştır. 11-20 yıl tecrübeye sahip katılımcılarda "Bilmiyorum" şıkkını işaretleme oranı yüksekken, istenen yanıtı verme oranı düşüktür $(p=0.038)$.

"Hemşire, eğer kasıtlı olarak yapmamış ise hatalı mesleki uygulamalarından sorumlu tutulamaz" şeklindeki 17. soruya katılımcıların \%64'ü $(n=388)$ yanlış, $\% 24,8$ 'i (n=150) bilmiyorum, \%10,4'ü (n=63) doğru biçiminde cevap verirken $\% 0,8^{\prime} \mathrm{i}(\mathrm{n}=5)$ ise soruyu yanıtsız bırakmıştır. Bu sorunun doğru cevabı "Yanlış" olup buna göre; katılımcıların \%64'ü soruyu doğru olarak yanıtlayabilmiştir. Farklı mezuniyet seviyesindeki katılımcıların cevapları arasında anlamlı farklılık saptanmıştır. Lise mezunlarının "Bilmiyorum" cevabını verme oranları düşük, yanılma oranları yüksektir ( $p=0.014)$. Eğitim almış olan katılımcılar ile eğitim almamış olanların cevapları arasında anlamlı farklılık saptanmıştır. "Bilmiyorum” cevabını verme oranı eğitim alanlarda düşük, eğitim almamış olanlarda ise yüksektir $(p=0.000)$. Farklı birimlerde çalışan katılımcıların cevapları arasında anlamlı farklılık saptanmamıştır $(p=0.062)$. Farklı mesleki tecrübe süresine sahip katılımcıların cevapları arasında anlamlı farklılık saptanmamıştır $(\mathrm{p}=0.799)$.

"Hemşire, hastasına ilişkin sırları hastanın ölümünden sonra açıklayabilir" şeklindeki 18. soruya katılımcıların \%76,1'i $(n=461)$ yanlış, \%20,6'sı $(n=125)$ bilmiyorum, \%3'ü $(\mathrm{n}=18)$ doğru biçiminde cevap verirken $\% 0,3$ 'ü $(n=2)$ soruyu yanıtsız bırakmıştır. Bu sorunun doğru cevabı "Yanlış" olup buna göre; katılımcıların $\% 76,1$ 'i soruyu doğru olarak yanıtlayabilmiştir. Farklı mezuniyet seviyesindeki katılımcıların cevapları arasında anlamlı farklılık saptanmıştır. Ön lisans mezunlarında "Bilmiyorum" cevabını verme oranı yüksek, istenen yanıtı verme oranı düşüktür $(p=0.004)$. Eğitim almış olan katılımcılar ile eğitim almamış olanların cevapları arasında anlamlı farklılık saptanmıştır. "Bilmiyorum" cevabını verme oranı; eğitim alanlarda düşük, eğitim almamış olanlarda ise yüksektir $(\mathrm{p}=0.000)$. Farklı birimlerde çalışan katılımcıların cevapları arasında anlamlı farklılık saptanmamıştır ( $\mathrm{p}=0.808)$. Farklı mesleki tecrübe süresi- ne sahip katılımcıların cevapları arasında anlamlı farkl1lık saptanmıştır. 11 yıl ve üzeri deneyime sahip olanlarda "Bilmiyorum" cevabını verme oranı yüksektir $(\mathrm{p}=0.012)$.

"Hemşire, tedavi sırasında öğrendiği hastaya ait sırları -hastanın açık rızası olsa bile- üçüncü şahıslara açıklamamakla yükümlüdür" şeklindeki 19. soruya katılımcıların \%61,1'i (n=370) doğru, \%21,8'i (n=132) bilmiyorum biçiminde yanıt vermiştir. Bu sorunun doğru cevabı "Yanlış" olup buna göre; katılımcıların \%16,3'ü soruyu doğru olarak yanıtlayabilmiştir (Grafik 3). Farklı mezuniyet seviyesindeki katılımcıların cevapları arasında anlamlı farklılık saptanmıştır. Ön lisans mezunlarında "Bilmiyorum" cevabını verme oranı yüksek, yanılma oranı düşüktür ( $\mathrm{p}=0.023)$. Eğitim almış olan katılımcılar ile eğitim almamış olanların cevapları arasında anlamlı farklılık saptanmıştır. "Bilmiyorum” cevabını verme oran1; eğitim alanlarda düşük, eğitim almamış olanlarda ise yüksektir $(\mathrm{p}=0.000)$. Farklı birimlerdeki katılımcıların cevapları arasında anlamlı farklılık saptanmıştır. Yanılma oranı; dahili tıp bilimlerinde çalışanlarda düşük, cerrahi tıp bilimlerinde çalışanlarda yüksektir $(\mathrm{p}=0.018)$. Farklı mesleki tecrübe süresine sahip katılımcıların cevapları arasında anlamlı farklılık saptanmıştır. 11-20 yıl tecrübeye sahip olanların "Bilmiyorum" cevabını verme oranı yüksek, yanılma oranı düşüktür ( $\mathrm{p}=0.007)$.

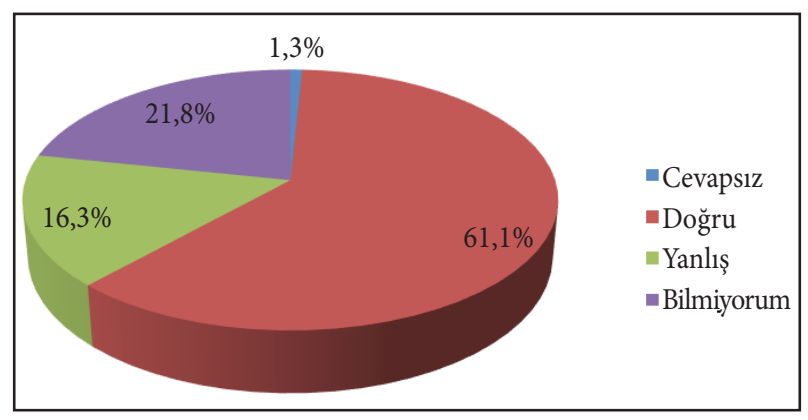

Grafik 3. "Hemşire, tedavi sırasında öğrendiği hastaya ait sırları -hastanın açık rızası olsa bile- üçüncü şahıslara açıklamamakla yükümlüdür” şeklindeki soruya verilen cevaplar.

"Hemşire, hasta/hasta yakını hakkında öğrendiği bilgiler sebebiyle mahkemede tanıklıktan çekinme hakkına sahiptir" şeklindeki 20. soruya katılımcıların \%63'9'u (n=387) bilmiyorum, \%24,4'ü (n=148) doğru, $\% 10,7$ 'si (n=65) yanlış biçiminde cevap verirken \%1'i $(\mathrm{n}=6)$ ise soruyu yanıtsız bırakmıştır. Bu sorunun doğru cevab1 "Doğru" olup buna göre; katılımciların 24,4'ü soruyu doğru olarak yanttlayabilmiştir. Farklı mezuniyet seviyesindeki katılımcıların cevapları arasında anlam- 
11 farkl1lık saptanmamıştır ( $\mathrm{p}=0.482)$. Eğitim almış olan katılımcılar ile eğitim almamış olanların cevapları arasında anlamlı farklılık saptanmamıştır $(\mathrm{p}=0.123)$. Farklı birimlerde çalışan katılımcıların cevapları arasında anlamlı farklılık saptanmamıştır $(\mathrm{p}=0.241)$. Farklı mesleki tecrübe süresine sahip katılımcıların cevapları arasında anlamlı farklılık saptanmamıştır $(\mathrm{p}=0.573)$.

"Hemşire, hasta / hasta yakınının açık rızasının varlığı halinde mahkemede tanıklık yapmak zorundadır" şeklindeki 21 . soruya katılımcıların \%62,7'si $(\mathrm{n}=380)$ bilmiyorum, \%22,4'ü $(\mathrm{n}=136)$ yanlış biçiminde yanıt vermiştir. Bu sorunun doğru cevabı "Doğru" olup buna göre; katılımcıların \%14,5'i soruyu doğru olarak yanıtlayabilmiştir (Grafik 4). Farklı mezuniyet seviyesindeki katılımcıların cevapları arasında anlamlı farklılık saptanmıştır. Yüksek lisans/doktora mezunlarının "Bilmiyorum" cevabını verme oranı düşük, istenen yanıtı verme oranı yüksektir ( $\mathrm{p}=0.004)$. Eğitim almış olan katılımcılar ile eğitim almamış olanların cevapları arasında anlamlı farklılık saptanmıştır. Eğitim alanlarda istenen cevabı verme oranı yüksektir $(p=0.006)$. Farklı birimlerde çalışan katılımcıların cevapları arasında anlamlı farklılık saptanmamıştır $(\mathrm{p}=0.096)$. Farklı mesleki tecrübe süresine sahip katılımcıların cevapları arasında anlamlı farklılık saptanmamıştır ( $\mathrm{p}=0.394)$.

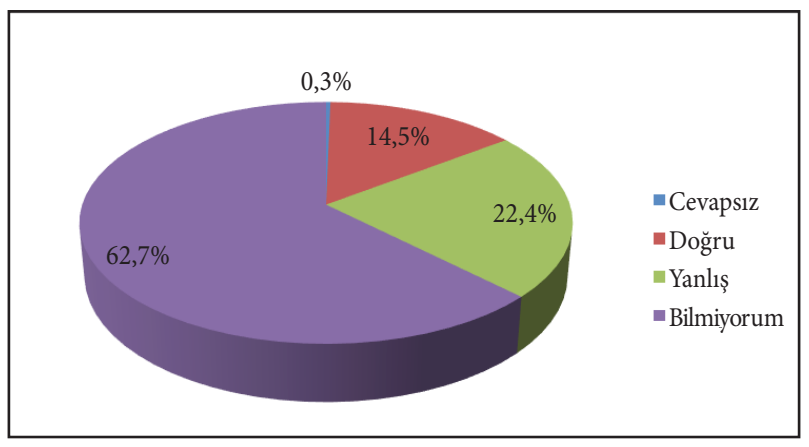

Grafik 4. "Hemşire, hasta / hasta yakınının açık rızasının varlığı halinde mahkemede tanıklık yapmak zorundadır" şeklindeki soruya verilen cevaplar.

"Bir hekim isteminde ilacın veriliş yolunun hatal olarak yazıldığını, hemşirenin de ilacı hekimin yazdiğ şekilde uyguladıktan sonra hastanın zarar gördügü̈nü ve bir ceza davası açıldı̆̆ını farz edelim. Buna göre;"

"Hekimin istemini uyguladığı için hemşire suçlu bulunmayacaktır" şeklindeki 22. soruya katılımc1ların \%57,3'ü $(n=347)$ yanlış, \%25,7'si $(n=156)$ doğru, $\% 16,5$ 'i $(n=100)$ bilmiyorum biçiminde cevap verirken $\% 0,5^{\prime} \mathrm{i}(\mathrm{n}=3)$ ise soruyu yanıtsız bırakmıştır. $\mathrm{Bu}$ soru- nun doğru cevabı "Yanlış" olup buna göre; katılımc1ların \%57,3'ü soruyu doğru olarak yanıtlayabilmiştir. Farklı mezuniyet seviyesindeki katılımcıların cevapları arasında anlamlı farklılık saptanmıştır. Lise mezunlarında "Bilmiyorum" cevabını verme oranı düşük, yanılma oranı yüksektir $(\mathrm{p}=0.009)$. Eğitim almış olan katılımcılar ile eğitim almamış olanların cevapları arasında anlamlı farklılık saptanmıştır. "Bilmiyorum" cevabını verme oranı eğitim alanlarda düşük, almamış olanlarda ise yüksektir $(\mathrm{p}=0.000)$. Farklı birimlerdeki katılımcıların cevapları arasında anlamlı farklılık saptanmıştır. Cerrahi tıp bilimlerinde çalışanlarda "Bilmiyorum" cevabını verme ve yanılma oranları yüksektir $(\mathrm{p}=0.010)$. Farklı mesleki tecrübe süresine sahip katılımcıların cevapları arasında anlamlı farklılık saptanmamıştır ( $\mathrm{p}=0.053)$.

"Hastaya zarar verebileceğini öngörmediği/kasten zarar vermediği için hemşirenin cezai sorumluluğu olmayacaktır" şeklindeki 23. soruya katılımcıların \% 43,7'si ( $\mathrm{n}=265)$ yanlış, \%30,7'si ( $\mathrm{n}=186$ ) bilmiyorum, $\% 25,1^{\prime} \mathrm{i}(\mathrm{n}=152)$ doğru biçiminde cevap verirken $\% 0,5$ ' $\mathrm{i}$ $(n=3)$ soruyu yanıtsız bırakmıştır. Bu sorunun doğru cevabı "Yanlış" olup buna göre; katılımcıların \%43,7'si soruyu doğru olarak yanıtlayabilmiştir. Farklı mezuniyet seviyesindeki katılımcıların cevapları arasında anlamlı farklılık saptanmıştır. Yanılma oranı ön lisans mezunlarında düşük, lisans mezunlarında yüksektir. Ön lisans mezunlarının sorulara "Bilmiyorum" şeklinde cevap verme oranı yüksektir ( $p=0.008)$. Eğitim almış olan katılımcılar ile eğitim almamış olanların cevapları arasında anlamlı farklılık saptanmıştır. "Bilmiyorum" cevabını verme oranı eğitim alanlarda düşük, almamış olanlarda ise yüksektir. Eğitim alanların soruya istenen cevabı verme oranı yüksektir $(\mathrm{p}=0.000)$. Farklı birimlerde çalışan katılımcıların cevapları arasında anlamlı farklılık saptanmamıştır $(\mathrm{p}=0.061)$. Farklı mesleki tecrübe süresine sahip katılımcıların cevapları arasında anlamlı farklılık saptanmıştır. 11-20 y1 deneyimi olanlarda "Bilmiyorum" cevabını verme oranı yüksek, istenen yanıtı verme oranı düşüktür $(\mathrm{p}=0.005)$.

"Cezai sorumluluk, uygulamayı yapan hemşireye değil; onun amiri olan başhemşireye ait olacaktır" şeklindeki 24. soruya katılımcıların $\% 71,5^{\prime} i(n=433)$ yanlış, \%26,1'i $(\mathrm{n}=158)$ bilmiyorum, $\% 2,1$ 'i $(\mathrm{n}=13)$ doğru biçiminde cevaplarken \%0,3'ü $(\mathrm{n}=2)$ ise soruyu yanıtsız bırakmıştır. Bu sorunun doğru cevabı "Yanlış" olup buna göre; katılımcıların \%71,5'i soruyu doğru olarak yanıtlayabilmiştir. Farklı mezuniyet seviyesindeki katılımc1ların cevapları arasında anlamlı farklılık saptanmamıştır $(p=0.966)$. Eğitim almış olan katılımcılar ile eğitim almamış olanların cevapları arasında anlamlı farklılık saptanmıştır. "Bilmiyorum" cevabını verme oranı eğitim alan- 
larda düşük, almamış olanlarda ise yüksektir $(\mathrm{p}=0.000)$. Farklı birimlerdeki katılımcıların cevapları arasında anlamlı farklılık saptanmıştır. Dahili tıp bilimlerinde çalışan hemşirelerde "Bilmiyorum" cevabını verme oranı düşük, istenen yanıtı verme oranı yüksektir $(\mathrm{p}=0.049)$. Farklı mesleki tecrübe süresine sahip katılımcıların cevapları arasında anlamlı farklılık saptanmamıştır $(\mathrm{p}=0.086)$.

"Ortaya çıkan zarardan tüm ekip (uygulamayı yapan hemşire, süpervizör hemşire, başhemşire, hekim...) sorumlu tutulacaktır" şeklindeki 25. soruya katılımcıların \%38,3'ü $(n=232)$ doğru, \%33'ü $(n=200)$ bilmiyorum, \%28,4'ü $(n=172)$ yanlış biçiminde cevap verirken $\% 0,3^{\prime} \ddot{\mathrm{u}}(\mathrm{n}=2)$ ise soruyu yanıtsız bırakmıştır. $\mathrm{Bu}$ sorunun doğru cevabı "Yanlış" olup buna göre; katılımc1ların \%28,4'ü soruyu doğru olarak yanıtlayabilmiştir. Farklı mezuniyet seviyesindeki katılımcıların cevapları arasında anlamlı farklılık saptanmıştır. Ön lisans mezunlarında "Bilmiyorum" cevabını ve istenen cevabı verme oranları yüksektir $(p=0.000)$. Eğitim almış olan katılımcılar ile eğitim almamış olanların cevapları arasında anlamlı farklılık saptanmıştır. "Bilmiyorum" cevabını verme oranı eğitim alanlarda düşük, almamış olanlarda ise yüksektir $(\mathrm{p}=0.000)$. Farklı birimlerde çalışan katılımcıların cevapları arasında anlamlı farklılık saptanmamıştır $(p=0.277)$. Farklı mesleki tecrübe süresine sahip katılımcıların cevapları arasında anlamlı farklılık saptanmıştır. 0-10 y1l deneyime sahip olanlarda "Bilmiyorum" cevab1nı verme oranı düşük, yanılma oranı yüksektir $(\mathrm{p}=0.000)$.

\section{Tartışma ve Sonuç}

Sonuçlar göstermektedir ki; eğitim seviyesi arttıkça istenen yanıtı verme oranı da artmaktadır. Liseden ön lisansa geçerken "Bilmiyorum" cevap oranının yükseldiği, ancak yanılma oranının azaldığı; yüksek lisans/doktora mezunlarında ise "Bilmiyorum" cevap oranının azaldığı, istenen cevabı verme oranının arttığı gözlenmektedir. $\mathrm{Bu}$ durum; hemşirelik eğitiminin seviyesi yükseldikçe adli/ tıbbi konularda farkındalığın da arttığını göstermektedir. Hemşirelerin eğitim düzeylerini üst seviyelere taşımaları gerektiği açıktır.

Konuya ilişkin eğitim alan katılımcılarda almayanlara göre "Bilmiyorum" cevabını verme oranlarının düşük olduğu ve istenen yanıtı verme oranlarının yüksek olduğu gözlenmektedir. Bu durum, eğitim almanın konuya ilişkin farkındalığı arttırdığını dolayısıyla da hizmet içi eğitimlerin ihmal edilmemesi gerektiğini göstermektedir. Öte yandan, eğitim alan katılımcıların "Hemşire, tedaviye bağlı olarak gelişen komplikasyonlardan sorumludur" şeklindeki 12. soruda yanılma oranlarının yüksek bulunması; konu hakkında yanlış bilgilendirilmelerinden veya konunun anlaşılmasının güç olmasından ya da sorunun yeterince açıklayıcı olmamasından dolayı kaynaklanıyor olabilir. Bu soruyla hemşirelerin kendi uygulamalarından kaynaklanan "komplikasyon" ile "tıbbi hata sonucu ortaya çıkan zarar" ayrımını bilip bilmediklerini ölçmek amaçlanmıştır. Ancak, bunun yeterince vurgulanmamış olması sorunun anlaşılmasında güçlük yaratmış ve hekim-hemşire uygulamaları karıştırılmış olabilir. Nitekim, Yılmaz (7) tarafından yapılan tez çalışmasında "Hekim istemine uygun olarak doğru hastaya, doğru dozda, doğru ilaç, doğru yoldan, doğru zamanda verilmiş ve hastanın alerji öyküsü de yokken uygulama sonrasinda hastada zarar meydan gelmişse bu duruma komplikasyon denir ve hemşire cezalandırılmaz" ifadesine katılımcıların \%90,9 gibi yüksek bir oranda doğru cevap vermiş olduğu belirtilmiştir.

Birimler arası farklılık çok az soruda ortaya çıkmaktadır. Üstelik önemli sayıda katılımıının hem cerrahi hem dahili tıp bilimlerinde çalışmış olması kanımızca sonuçların kesinliğini etkilemektedir. Hem cerrahi hem dahili tıp bilimlerinde çalışan katılımcılar birimlere göre etkili bir şekilde sınıflandırılamamış, limitasyon oluşturulmuştur. Sonuçlar; yapılacak olan eğitimlerin branş ve alan farkı gözetmeksizin yapılabileceğini ortaya koymaktadır. Elbette alana has sorunlar özel toplantı ve eğitimler ile tartışılabilir ve bilgilendirme yapılabilir.

0-10 yıl tecrübeye sahip olanların yanılma oranlarının yüksek olduğu, 11 yıl ve üzeri tecrübeye sahip olanların ise; bilmediklerini ifade ettikleri soru oranının yüksek olduğu ve yanılma oranlarının nispeten daha düşük olduğu gözlenmektedir. Bu durumda; 11 yıl ve üzeri tecrübeye sahip olanların sorulara daha temkinli yaklaştıklarını söylemek yanlış olmaz. Ancak bu farklılık hiçbir zaman yeterli görülmemeli ve hizmet içi eğitimler kıdemli hemşirelerde de kesintisiz olarak sürdürülmelidir.

Sorulara verilen yanıtlar göstermektedir ki; hemşirelerin önemli bir bölümü tabi oldukları mevzuatı bilmemekte veya yanlış bilmektedir. Ülkemizde konuyla ilgili yapılan sınırlı sayıda çalışmada da hemşirelerin mesleki mevzuat hakkındaki bilgi düzeyleri yetersiz bulunmuştur $(3,8,9)$. Bu durum, mesleki uygulamaları ve muhtemel hukuksal sorumlulukları bakımından sakıncalıdır. Konu ile ilgili olarak hem lisans düzeyinde, hem de mezuniyet sonrasında yeterli eğitim verilmelidir. Mezuniyet sonras1 eğitimler belirli zaman aralıkları ile tekrarlanmalıdır. Elbette ki sözü edilen eğitimlerin kimler tarafından verileceği de önemlidir. Kanımızca bu eğitimlerin adli hemşireler tarafından verilmesi yerinde olacaktır. Bu bağlamda, hemşireler aleyhine açılan malpraktis davalarında bilirkişi olarak sadece hekimlerin görev alması da uygun değildir. Bu konuda bilirkişi olarak yine adli hemşirelerin veya alanlarında uzman hemşirelerin görev almasının daha uygun olacağ 1 düşüncesindeyiz. 


\section{Kaynaklar}

1. Abaan S. Hekim istemleri ve hemşirenin yasal sorumluluğu. Cumhuriyet Üniversitesi Hemşirelik Yüksekokulu Dergisi. 1997;1(1):1-8

2. Velioğlu P, Babadağ K. Hemşirelik tarihi ve deontolojisi. Anadolu Üniversitesi Açık Öğretim Fakültesi Yayınları. 1992. p. 103.

3. Güler S. Hemşirelerin Mesleki Yaşamlarında Karşılaştıkları Hukuki Sorunlar ve Başa Çıkma Yolları [master's thesis]. [İstanbul]: İstanbul Üniversitesi Sağlı Bilimleri Enstitüsü;1997.

4. Kuğuoğlu S, Çövener Ç, Kürtüncü M, Aktaş E. İlaç uygulamalarında hemşirenin mesleki ve yasal sorumluluğu. Maltepe Üniversitesi Hemşirelik Bilim ve Sanatı Dergisi. 2009;2(2):89-93

5. Türk Ceza Kanunu. Türk Ceza Kanunları Yasa Serisi. Yayın No:30. İstanbul: Yaylım Yayıncılık, 2008:9-137.
6. Kahraman B. Yönetici Hemşirelerin Hemşirelik Hizmetleri Personelini Yönetirken Yaşadıkları Sorunlar ve Bu Sorunlara Karşı Alınan Önlemler [master's thesis]. [İstanbul]: İstanbul Üniversitesi Sağlık Bilimleri Enstitüsü; 2007.

7. Yılmaz ÖA. Hemşirelerin Türk Ceza Kanunu'nun Hemşirelik Uygulamalarına Yönelik Maddeleriyle İlgili Bilgi Düzeylerinin Belirlenmesi [master's thesis]. [İstanbul]: İstanbul Üniversitesi Sağlık Bilimleri Enstitüsü; 2010.

8. Ilgan C. Hemşirelerin Mesleki Mevzuat Hakkındaki Bilgi Düzeylerinin Araştırılması [master's thesis]. [Ankara]: Gülhane Askeri Tıp Akademisi Sağlık Bilimleri Enstitüsü; 2005.

9. Batmaz M, Akbal Y, Pekçetin Ç. Hemşirelerin Sağlık Mevzuatında Kendilerini İlgilendiren Konularla İlgili Bilgi Düzeylerinin Araştırılması. II. Ulusal Hemşirelik Kongresi. İzmir; 1990. 